\section{UNIVERSITY \\ of DEBRECEN}

FACULTY OF

HEALTH

NYÍREGYHÁZA

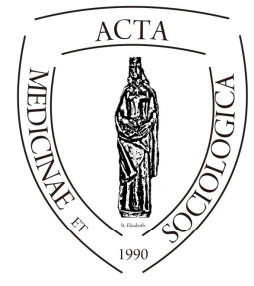

ACTA

MEDSOC

VOLUME 3.

2013

\title{
Két módszer, egy minta Az egocentrikus kapcsolati háló vizsgálata névgenerátorral és network napló módszerrel
}

\author{
Huszti Éva \\ Debreceni Egyetem, Egészségügyi Kar
}

'Empirical collection of contact data is possible but not easy...'

Pool and Kochen, 1978:19

\begin{abstract}
We have known many methods to measure ego-centred network. All applied methods have advantages and disadvantages, strong and weak points. In this study I deal with one of the most often applied method, name generator and an alternative data collecting method that is used rarely even internationally, contact diary. In Hungary Róbert Angelusz and me developed and tested this method. In this paper I examined the network size and composition which were measured by name generator and contact diary in the same sample.
\end{abstract}

Keywords: personal network, name generator, contact diary, network size, network composition

DOI: $10.19055 / \mathrm{ams} .2013 .4 / 11 / 5$ 


\section{Bevezetés}

Az egyéni kapcsolathálózatok feltárásának több módszerét is ismerjük. Minden alkalmazott módszernek vannak előnyei, hátrányai, erősebb és gyengébb oldalai. Tanulmányomban az egyik leggyakrabban használt módszerrel, a névgenerátorral, illetve az egyik, nemzetközi téren kevéssé, hazánkban pedig még egyáltalán nem alkalmazott módszerrel, a kapcsolati naplóval foglalkozom. A lentebb bemutatásra kerülő kapcsolati napló kialakításának, formálásának, tesztelésének igénye Angelusz Róbert nevét dicséri, az ő témavezetésével kezdtem el az általa network naplónak nevezett módszerrel foglalkozni. Jelen írás a névgenerátorral és a network naplóval mért egocentrikus kapcsolati háló méretét és összetételét vizsgálja. A két módszer összehasonlításához a Nyíregyháza Életminősége panelkutatáshoz használt mintából kialakított alminta nyújtotta az alapot. ${ }^{1}$ Az adatfelvételre 2010-ben és 2011-ben került sor.

\section{Alkalmazott adatgyüjtési módszerekről általában}

Az elmúlt négy évtizedben a különbözö típusú névgenerátorok voltak a legfontosabb mérési módszerek, melyek közelebb vitték a kutatókat az egocentrikus kapcsolati háló megismeréséhez. Az egocentrikus kapcsolati háló felmérésének két leggyakrabban alkalmazott, legnépszerübb módszere a Wellman, Fischer, Burt, Marsden neveihez köthetö névgenerátor ${ }^{2}$, valamint az elsősorban Lin és Dumin nevével fémjelzett pozíció generátor ${ }^{3}$. Mindkét módszer elsődleges célja, hogy az egyéni kapcsolatrendszer társas támogatását és a kapcsolatok által elérhető erőforrásokat próbálja feltárni. A két módszer között azonban fontos metodológia és teoretikus különbségek vannak (Chua-Madej-Wellman, 2009). A névgenerátor és a pozíciógenerátor mellett az erőforrás generátort kell még meg-

\footnotetext{
${ }^{1}$ Nyíregyháza Megyei Jogú Város Polgármesteri Hivatal Szociális Osztálya és a Debreceni Egyetem Egészségügyi Kar Alkalmazott Társadalomtudományi Tanszéke által 2008-ban indított kutatássorozat célja a városban élők életminőségének panelszerü vizsgálata. A panelkutatás során alkalmazott mintába a 18. életévüket betöltött állandó nyíregyházi lakosok kerültek be. A minta kiválasztását a Közigazgatási és Elektronikus Közszolgáltatások Központi Hivatala végezte véletlenszerüen. Így első körben egy 2000 főből álló minta jött létre, melyet egy 400 fős pótminta egészített ki. Az így összeállított minta a nem változó mentén reprezentálja a város lakosságát. A saját kutatásom során használt mintát tehát ebből az adatbázisból állítottam össze, ez volt a mintavételi keret.

2 továbbá pl. Laumann, 1973; Wellman, 1979; McCallister and Fischer, 1978; Fischer, 1982; Burt, 1984; Campbell and Lee, 1991; Marsden, 1987

${ }^{3}$ továbbá pl. Lin and Dumin, 1986; Lin, 2001; Erickson, 2004
} 
említeni, mint a kapcsolati hálót vizsgáló módszer (Snijders, 1999, van der Gaag and Snijders, 2004). Negyedik útként a napló módszert lehet említeni, mely során a kutató arra kéri a válaszadót, hogy soroljon fel minden egyes kapcsolatát napi szinten, egy bizonyos időintervallumon keresztül. A továbbiakban a névgenerátorral, valamint a napló módszerrel foglalkozom részletesebben.

\section{A névgenerátor}

Az egyéni kapcsolatrendszerről szóló adatgyüjtés alapvetően azon alapul, hogy felvázoljuk az egyének (ego) kapcsolatait más emberekkel (alterek). Módszertanilag az adatgyüjtés első lépése, hogy az interjúkészítő/kérdezőbiztos azt kérdezi az egyénektől, hogy kikkel állnak kapcsolatban. Az ego által felsorol altereket tekintik az adott ego társas kapcsolatrendszerének. A következő lépésben a kutatások ezekről az alterekröl gyüjtenek információkat (pl. Wellman, 1979, 2001a, 2001b; Fischer, 1982a, 1982b; Hogan, Carrasco and Wellman, 2007). A névgenerátor alapesetben azt kéri a válaszadótól, hogy adjon egy listát azokról a kapcsolatairól, akik eleget tesznek bizonyos, előre megadott kritériumoknak, pl. erős kapcsolatok, barátok, stb. (pl. Fischer, 1982a, 1982b; Wellman, 1979). Vannak kutatások, melyekben egyszerüen azt kérdezték meg az emberektől, hogy „,Ki az Ön legjobb barátja?” (Laumann, 1973), vagy azt, hogy kik azok, akikkel ,intim", közeli kapcsolatban van a megkérdezett (Wellman, 1979). Mások azt kérték a megkérdezettől, hogy nevezzék meg azokat, akikkel bizonyos erőforrásokat tudnak cserélni, pl. akitől kölcsön tud kérni adott esetben egy nagyobb öszszeget, vagy akitől tanácsot kér munkával kapcsolatos döntésben (Fischer, 1982a). A tapasztalatok szerint ez utóbbi megközelítés több nevet tár fel, mint az első típusú, viszont kimaradnak az olyan kapcsolatok, akik nem nyújtanak társas támogatást (Chua-Madej-Wellman, 2009). Ezek az alkalmazási módok az egyéni networknek az ún. mag-kapcsolatainak (core regions of personal networks) feltárására koncentrálnak, kivéve pl. a Granovetter által használt névgenerátor, mely tartalmazott egy olyan kérdést (munkahelykeresés), mely a gyengébb, de fontos kapcsolatokat is feltárta (Granovetter, 1973, 1974, 1982). Az általában alkalmazott névgenerátorok afelé tendálnak, hogy szinte csak az erős kötések feltárására törekszenek (Chua-Madej-Wellman, 2009).

A névgenerátor kérdéseket általában ún. névinterpretáló kérdések követik, melyek arra irányulnak, hogy különböző paraméterek alapján leírják az ego által megnevezett egyes altereket, illetve, hogy képet adjanak ego és az egyes alterek kapcsolatáról (Marsden, 2005). A névinterpretáló kérdések magukba foglalnak olyan kérdéseket, mint a 1) személyes jegyeket leíró kérdések - az alter neme, kora, iskolai végzettsége, szocio-ökonómiai háttere; 2) a kötések leírására szol- 
gáló kérdések - ego-alter közötti kapcsolat típusa (szerep szerint), a kapcsolat gyakorisága, az intimitás szintje, a kötés élettartama, eredete (Chua-MadejWellman, 2009).

A névgenerátor viszonylag részletes információt ad az egyén kapcsolatrendszeréröl, a kitöltésével kapcsolatban azonban több esetben fogalmazódott meg, hogy a kitöltés nagyon időigényes lehet (Fu, 2007). Ennek kiküszöbölésére született például a 'participant-aided sociograms' (Hogan, Carrasco, Wellman, 2007), mint egy innovatív módszer. Ez az „alacsony technológiájú” módszer (papír, ceruza, post-it) arra kéri a megkérdezetteket, hogy sorolják fel, majd egy koncentrikus körökből álló ábrára helyezzék el azoknak a személyeknek a neveit, akikkel kapcsolatban állnak. A koncentrikus körök mindegyike különbözö intimitási szintet képvisel. A megkérdezett van a legbelső körben, öt közvetlenül a szoros kapcsolatai veszik körül, aztán a kevésbé szoros, majd a gyengébb kötések következnek.

\section{Kapcsolati napló}

A kapcsolati napló módszert 1961-ben Gurevitch alkalmazta először: 100 napon keresztül 18 személy vezette a naplót az USA-ban. Az egonak azokat az altereket kellett megjelölnie és szociodemográfiai adatok mentén jellemeznie, akivel az egyes napokon találkoztak. A módszerrel sikerült feltárni a megkérdezettek kapcsolatrendszeréhez tartozók társas struktúráját (Fu, 2007). Pool és Kochen (1978) azt kérték a válaszadóktól, hogy egy jegyzettömbbe írjanak fel mindenkit, akikkel találkoztak. Csak azokat az ismerősöket kellett feljegyezni, akikkel az adott időintervallumon belül legalább két alkalommal találkoztak, akiknek tudták a nevét, és akiket legalább üdvözöltek. Freeman és Thompson az 1980-as évek végén tettek kíséreltet az ismerősök alkotta network méretének becslésére. A szerzőpáros szerint a naplós adatfelvétellel azokra a másokra lehet jó becslést adni, akik a megkérdezettek teljes ismerősi köréből a vizsgált időszakban aktív kapcsolatot mutattak (Freeman-Thompson, 1989). Lonkila (1999) Oroszországban és Finnországban középiskolai tanárok kapcsolati rendszerét vizsgálta, akiknek 15 napig kellett feljegyezniük a „nem rutinszerü” kapcsolataikat. Legújabban a taiwan-i Yang-chih Fu foglalkozik részletesen és évek óta az egyéni kapcsolatháló napló módszerrel történő vizsgálatával. Fu szerint több okból kifolyólag is nehéz pontosan meghatározni az egyént körülvevő kapcsolati rendszert. Egyrészt, nincsenek tiszta határok az egocentrikus network körül, másrészt, pedig minden egyéni networknek van egyfajta dinamikája, tehát az idő folyamán a network tagok cserélőd(het)nek (Fu, 2005). Fu 2005-ös tanulmányában két módszert vetett össze: 
1. single-item survey - „Hozzávetőlegesen hány emberrel találkozik naponta?" A kérdést zárt formában teszik fel, tehát a megkérdezett különböző válaszlehetőségek közül választhat. pl. 0-4 fö vagy pl. több mint 100 fö. A módszer olcsó ugyan, de meglehetősen kevés információ nyerhető belőle az egyén tényleges kapcsolatrendszerét illetően.

2. napló módszer (diary log) - általában kevés számú válaszadót kérnek meg arra, hogy egy bizonyos időszakon keresztül naplót vezessen napi kapcsolatairól, majd részletes leírást adjon a naplóban megjelölt személyekről és a velük való kapcsolatáról. Ez a módszer meglehetősen költséges, viszont lényegesen több információt ad, mint a másik típusú adatfelvétel.

Fu meglátása szerint a fenti két módszer lényegesen különbözik ugyan egymástól, de olyan adatokat generálnak, melyek jól kiegészítik egymást. Ezen a vonalon haladva, ezt továbbgondolva vetem össze az általam alkalmazott névgenerátor és napló módszer eredményeit. A legfontosabb indok, ami miatt a névgenerátorral való összevetést választottam az, hogy a napló módszer előzetes tesztelése során talált eredmények azt mutatták, hogy sok, klasszikusan az erős kötéshez sorolt kapcsolatot tár fel a napló is, de azokon felül vannak olyan bejegyzett alterek, akik nem sorolhatók egyértelmúen sem az erős, sem pedig az általánosan elfogadott tipológia másik végletéhez tartozó gyenge kötésekhez sem.

\section{A napló módszer előnyei a korábbi tapasztalatok alapján}

Annak ellenére, hogy a napló nagyon munkaigényes feladat, a tapasztalatok szerint a módszerrel a kapcsolatok értékes tartományát lehet felmérni az erős kötésektől a közepesen erős kapcsolatokon keresztül a gyenge kötésekig, melyek sem a névgenerátor, sem pedig a pozíciógenerátorral nem ismerhetők meg (Chua-Madej-Wellman, 2009).

A különböző típusú generátor módszerektől eltérően, a naplóban feljegyzett napi kapcsolatok pontosabban mutatják azokat a társas cselekvéseket, melyek formálják és fenntartják a kapcsolati háló struktúráját. A napló módszer így direkt és átfogó eleme lehet az egocentrikus network mérésének.

Míg a névgenerátor feltárja az erős kapcsolatokat, a pozíciógenerátor módszer a gyenge kötéseket, addig a napló egyszerre ad információt a különböző típusú kapcsolatokról. A napló nyilvánvaló korlátai és rizikói ellenére a belöle származó adatok felölelik mind az erős, mind a gyenge kötéseket. A napló adataiból láthatjuk, hogy milyen gyenge kötései vannak egonak és milyen kapcsolata van idegenekkel, valamint azt is, hogy az intim, közeli alterekkel való kapcsolat hogyan formálódik (Killworth et al., 1990).

Egy jól strukturált és irányított network naplóval lehet csökkenteni az emlékezet és felidézés problémáját, mely alapvetően nehezíti az egocentrikus network pon- 
tos vizsgálatát. Fu mutat rá arra az előnyre is, hogy míg a generátor módszerek különböző becsléseket adnak a komplett networkre vagy annak egyes részhalmazaira, a kapcsolati napló az egyéni network egy teljesebb profilját állítja elő. A napló az aktuális és komplett network-öt méri egy meghatározott időintervallumban (Fu, 2005). Az eddigi alkalmazások bizonyítják, hogy a naplóból származó információ nagyon gazdag, és részletes. Ezek az előnyök nagymértékben tompítják azt, hogy költséges, időt és energiát igénylő módszer a naplózás. Az egyéni kapcsolatháló dinamikus, a kapcsolatok, így maga a network is állandóan formálódik az interakciók és cselekvések közben. A napi kapcsolatok, megvalósuló interakciók, cselekvések vizsgálata alapvető eleme kell legyen a társas kötések tanulmányozásának, hiszen ezekből ismerhetjük meg az egyéni kapcsolatrendszer felépítését, alakulását. Ennek vizsgálatára a legpraktikusabb módszer a napló (Fu, 2008). Mindezek mellett a napló lehetővé teszi, hogy a kutatók az aktuális, első kézből származó és teljes kapcsolati adatokat gyüjtsék be az egyéni kapcsolathálót illetően, valamint a kutatók arról is képet kapnak, hogy ego hogyan érzékeli és értékeli az alterekkel való kapcsolatát. (Fu, 2005)

\section{A napló módszer kritikái}

A napló módszer pioneer alkalmazásai során már látható volt, hogy a naplók kitöltése időigényes, és nagy kérés a naplót vezetőktől. Ezt többféle módon próbálták kiküszöbölni: pl. nem idötartamot határoznak meg, hanem azt, hogy pl. 100 kapcsolatot jegyezzenek fel. (Fu, 2007) Vannak, akik szerint a rövid periódus (ide tartozik még az egy hét is), illékony képet mutat az egyén kapcsolati hálójáról és a hosszabb periódus mindenképpen stabilabb képet mutat (FeldSuitor-Hoegh, 2007).

Mivel a kapcsolati napló csak azokat az altereket tartalmazza, akikkel az ego a meghatározott időintervallumban találkozik, így nem használható globális és hosszabb távra is vonatkozó kapcsolati háló feltárására. Fu szerint azonban azok a kapcsolatok, melyek nem jelennek meg az adatfelvétel során, nem is számítanak az ego aktív kapcsolatai közé. (Fu, 2007). Az általam alkalmazott naplóban az egy hetes napló után lehetőség volt megjelölni azokat az altereket, akikkel az adott héten nem találkozott ego, de valami miatt fontosak számára (lásd még Lonkila, 1999).

További hiátus, hogy a válaszadók nagyobb valószínűséggel idézik fel azokat a kapcsolatokat, melyek időben hosszabbak vagy érzelmileg intenzívebbek. Fu azt mondja, hogy a napló pontos tervezése, a válaszadók pontos instruálása, segítése ezt a problémát minimálisra tudja csökkenteni (Fu, 2007). Freeman és Thompson (1989) szerint a napló módszer túlságosan fárasztó és költséges módszer ahhoz, hogy empirikus kutatásokra használjuk. Nem lehet nagy és reprezentatív mintán alkalmazni, és nem lehet pontosan meghatározni azt az időtartamot, ameddig vezetni kell a naplót. A túl hosszú ideig vezetendő napló az ésszerü 
feleleti arányt csökkenti. Fu amellett érvel, hogy a kevés elemszámú, de informatív naplók viszont mindenképpen értékes eredmények és illusztratívak bizonyos személyes kapcsolati hálókra vonatkozóan. (Fu, 2007) A naplós adatfelvételek során az alterekről sok esetben több információval rendelkezünk, mint a megkérdezettről. Ez felvethet etikai jellegü kérdéseket is.

Véleményem szerint az egocentrikus kapcsolati háló kutatására alkalmazott módszerek az egyént körülvevő kapcsolatrendszernek csak egy kis szeletét mutatják be, ezért szükséges egy olyan metódus, mellyel az egyéni network szélesebb körét lehet vizsgálni. Előny, hogy a napló módszerrel a személyes network nagyobb részét lehet megismerni, mint a névgenerátor módszerrel, de a megismert alterek mégsem lesznek anonimek, mint például az egyébként tágabb kapcsolati hálót is befogni képes, pozíciógenerátor módszerrel gyüjthető adatok. Meglátásom szerint a névgenerátor módszerek legnagyobb rizikója, hogy ezek a módszerek alapvetően a vizsgált személyek vélt kapcsolatait tárják fel. Az egyes szituációk esetén megnevezett alterekkel kapcsolatban nem megvalósult kontaktusokat kell feljegyezni, hanem azt, hogy vajon, az adott élethelyzetben a megkérdezett szubjektív megítélése szerint kire számíthat. Végeredményben tehát, lehetséges, hogy kezelhetőbb listát kapunk az ego-t körülvevő kapcsolatrendszerről a különböző szempontok alapján limitált névgenerátor módszerek alkalmazásával, de ezzel, véleményem szerint információt veszíthetünk, és nem feltétlenül a valós és aktuális kapcsolatrendszert ismertjük meg.

\section{Adatfelvétel, minta}

Az általam fejlesztett és tesztelt network napló müködését Nyíregyháza Megyei Jogú Város lakosai körében volt módomban vizsgálni. A naplóval végzett adatfelvétel a már említett nyíregyházi panelvizsgálatban alkalmazott mintára épült. A kérdezési időpont kiválasztásánál figyeltem arra, hogy az adott időszakra ne essen semmilyen ünnep, ne legyen benne munkaszüneti nap, azaz egy-egy áltagos hét vizsgálatára törekedtem. Az adatfelvételi szituáció mindkét időpontban hasonlóan történt, azaz az előre felkészített kérdezőbiztosok (szociális munkás hallgatók) a megadott címek alapján felkeresték a mintába kerülöket, akikkel, első alkalommal közösen töltöttek ki egy névgenerátor típusú kérdőívet, majd a napló módszer ismertetése után, ugyancsak közösen, elkezdték kitölteni a naplót az adott napra vonatkozóan. A módszer közös megismerését, a kezdeti közös kitöltést Szalai alapján „nevelö interjúnak” nevezhetjük, melynek esetükben is az volt a célja, hogy növelje a módszer megbízhatóságát (Szalai, 1978). Az instrukciók alapján a naplóvezetés egy hete alatt a kérdezőbiztos legalább egyszer felkereste a megkérdezettet, vagy az utolsó találkozás alkalmával átnézték az 
elkészített naplót, pontosították a névinterpretáló kérdésekre adott válaszokat. A mintába került válaszadók mindegyikével készült tehát egy Fischer-féle névgenerátor típusú kérdőív (McCallister-Fisher, 1978) és egy kapcsolati napló, melyet egy hétig kellett vezetniük a megkérdezetteknek.

$\mathrm{Az}$ adatfelvétel két szakaszban történt. Mindkét alkalommal két módszert alkalmaztunk: a hét szituációs névgenerátort és a naplót. A névgenerátor hét szituációt tartalmazott, melyek az instrumentális (2.; 3.; 4. szituációk), emocionális segítő kapcsolatokat (5.; 6.; 7. szituációk )és a szabadidő eltöltésekor szóba jöhető kapcsolatokat mérték (1. szituáció) ${ }^{4}$.

\begin{tabular}{|c|c|c|}
\hline Az adatfelvétel ideje & Névgenerátor & Napló \\
\hline 2010 tavasz & 60 & 60 \\
\hline 2011 ősz & 82 & 82 \\
\hline Összesen & 142 & 142 \\
\hline
\end{tabular}

1. számú táblázat

Adatfelvétel és módszer

A megkérdezettek (egok) demográfiai jellemzöi: a megkérdezettek körében némiképp felülreprezentált a nők csoportja ${ }^{5}$. A megkérdezettek átlagéletkora 45 év. Iskolai végzettségüket tekintve legtöbben középiskolai végzettséggel rendelkeznek Mind a korosztályokat, mind, pedig a megkérdezettek iskolai végzettségét tekintve elmondható, hogy minden kategóriából előfordultak a naplót kitöltők között, tehát a mérési bázis meglehetősen tág körủ volt.

A névgenerátorban szereplö megnevezettek (alterek) demográfiai jellemzöi: az egyének által megjelölt alterek 45\%-a férfi, 55\%-a pedig nő. Az alterek átlagéletkora 42 év (median $=40$; mode $=40$; std. dev. $=16,56$ ), a legfiatalabb megjelölt 3 , a legidősebb, pedig 92 éves volt. Az alterek több mint fele $(55,3 \%)$ valamilyen típusú (gimnázium, szakközép, szakiskola/szakmunkásképzö) középiskolai végzettséggel rendelkezik, harmaduk $(32,3 \%)$ befejezett felsőfokú végzettséggel, 12,5\%-uk maximum 8 általános iskolai osztályt végzettséggel bír.

\footnotetext{
${ }^{4}$ A névgenerátorban alkalmazott szituációkat lásd Függelék 1.

${ }^{5}$ Nyíregyházán 2001-es népszámlálás szerint 46,8-53,2\% a nemi megoszlás. Meg kell azonban azt is jegyezni, hogy a naplós adatfelvétel során nem torzult annyira a minta, mint a panelvizsgálat során, mikor is a megkérdezés után 38,9-61,1\%-ra módosult a nemek aránya a mintában, így súlyozni kellett az adatokat.
} 


\begin{tabular}{|c|c|c|c|c|c|c|}
\hline & \multirow{2}{*}{\multicolumn{2}{|c|}{ Ego }} & \multicolumn{4}{|c|}{ Alter } \\
\hline & & & \multicolumn{2}{|c|}{ Névgenerátor } & \multicolumn{2}{|c|}{ Napló } \\
\hline & $\mathbf{N}$ & $\%$ & $\mathbf{N}$ & $\%$ & $\mathbf{N}$ & $\%$ \\
\hline $\begin{array}{ll}\text { nem } & \\
\text { - férfi } \\
\text { - nö } \\
& \mathbf{N}=\end{array}$ & $\begin{array}{c}58 \\
78 \\
136\end{array}$ & $\begin{array}{l}43 \\
57\end{array}$ & $\begin{array}{c}593 \\
721 \\
\mathbf{1 3 1 4}\end{array}$ & $\begin{array}{l}45 \\
55\end{array}$ & $\begin{array}{c}1212 \\
1364 \\
\text { 2576* }^{*}\end{array}$ & $\begin{array}{l}47 \\
53\end{array}$ \\
\hline $\begin{array}{ll}\text { kor } & \\
\text { - } & >18 \text { éves } \\
\text { - } & 18-29 \text { éves } \\
\text { - } & 30-39 \text { éves } \\
\text { - } & 40-49 \text { éves } \\
\text { - } & 50-59 \text { éves } \\
\text { - } & 60-69 \text { éves } \\
\text { - } & 70 \text { és }< \\
& \mathbf{N}=\end{array}$ & $\begin{array}{c}0 \\
26 \\
32 \\
23 \\
23 \\
19 \\
17 \\
\mathbf{1 4 0 *}\end{array}$ & $\begin{array}{c}0 \\
19 \\
23 \\
16 \\
16 \\
14 \\
12\end{array}$ & $\begin{array}{c}58 \\
256 \\
314 \\
228 \\
210 \\
162 \\
87 \\
\mathbf{8 8 2 *}\end{array}$ & $\begin{array}{c}4 \\
20 \\
24 \\
17 \\
16 \\
12 \\
7\end{array}$ & $\begin{array}{c}137 \\
524 \\
593 \\
474 \\
425 \\
262 \\
116 \\
\text { 2531* }\end{array}$ & $\begin{array}{c}5 \\
21 \\
23 \\
19 \\
17 \\
10 \\
5\end{array}$ \\
\hline $\begin{array}{l}\text { iskolai végzettség } \\
\text { - max. általános iskola } \\
\text { - középiskola } \\
\text { - föiskola/egyetem } \\
\quad \mathbf{N}=\end{array}$ & $\begin{array}{r}12 \\
78 \\
41 \\
131 *\end{array}$ & $\begin{array}{c}9 \\
60 \\
31\end{array}$ & $\begin{array}{c}160 \\
710 \\
414 \\
1284 *\end{array}$ & $\begin{array}{l}13 \\
55 \\
32\end{array}$ & $\begin{array}{c}272 \\
1412 \\
795 \\
\mathbf{2 4 7 9 *}\end{array}$ & $\begin{array}{l}11 \\
57 \\
32\end{array}$ \\
\hline
\end{tabular}

*Az egyes jellemzők közötti $\mathrm{N}$ különbsége a válaszhiányokból adódik.

2. számú táblázat

Az EGO-k illetve az Ego-k által felsorolt ALTER-ek demográfiai jellemzői

A naplóban szereplö megnevezettek (alterek) demográfiai jellemzői: a megkérdezettek által megjelölt alterek 47\%-a férfi, 53\%-a nö. A naplóban megjelölt alterek átlagéletkora 40,64 év (median=40; mode=40; std.dev.=16,49), a legfiatalabb alter 1 éves, a legidősebb, pedig 94 éves volt. A naplóba bejegyzett alterek több mint felének (57\%) középiskolai végzettsége, harmaduknak $(32 \%)$ valamilyen felsőfokú végzettsége, minden tizedikük (11\%) pedig maximum általános iskolai végzettséggel bír.

A megkérdezettek átlagéletkora kicsivel magasabb (45év), mint az általuk akár a névgenerátorban (42 év), akár a naplóban megjelölt altereké (41 év). Mind a megkérdezettek, mind az általuk megjelöltek körében magasabb a nők aránya. A megkérdezettek legnagyobb aránya a 30-39 éves korosztályba tartozik és ez elmondható az alterekről is. Az iskolai végzettség szerint is a homogenitás jel- 
lemző mindkét módszerrel mért alterek esetében, hiszen az ego-k és az alterek is zömében valamilyen középiskolai végzettséggel rendelkeznek.

A két módszer tehát az alterekre vonatkozóan nagyon hasonló megoszlásokat mutat a fenti változók mentén.

\section{A kutatásban alkalmazott network napló}

A napló napi rendszerességgel vizsgálja az ego kapcsolathálóját egy meghatározott időintervallumban. Formátumának, tartalmának megválasztása, végső kialakítása a minél hatékonyabb felhasználhatóság miatt időigényes volt, ezért több körös tesztelés előzte meg a végső formát. Első, kiinduló formájában a napló egy úgynevezett sima, $\mathrm{A} / 5$ méretü füzet volt, melynek belső borítóján egy rövid instrukció szerepelt, melyben arra kértem a naplót kitöltőt, hogy jegyezze le azt, hogy kikkel találkozott az általam elöre megadott napszakokban. Mivel nem állt szándékomban elöre strukturálni a naplót, - ezzel is teret engedve annak, hogy a kitöltő maga találja ki a naplóvezetés módját - a hét napjait osztottam fel 6 szakaszra: pl. hétfő reggel, délelőtt, délben, délután, este, éjszaka. A network naplót egy hétig kellett vezetniük a kitöltőknek már a tesztelés szakaszában is. A network napló végső formája egy 18 oldalas, füzetszerúen összefüzött ív lett. A végső változat kialakítása során törekedtem minél jobban használható, „felhasználóbarát" verziót szerkeszteni. Ehhez figyelembe vettem a pioneer kutatások, illetve $\mathrm{Fu}$ tapasztalatait, illetve az időmérleg kutatások gyakorlatát is. Az egyik leggyakrabban megfogalmazott probléma az emlékezetből fakadó torzítások, adatkiesések voltak, ezért próbáltam minél jobban „támogatni az emlékezetet”. A napló belső borítója egy rövid bevezetőt tartalmaz arról, hogy milyen témával fog találkozni a naplót kitöltő. Ezt a szöveget igyekeztem egyszerủen, mindenki számára világosan, könnyen értelmezhetően megfogalmazni. A naplóhoz ajánlást is mellékeltem, mely olyan praktikákat tartalmaz, melyek ismeretében könynyebben lehet kitölteni a naplót. Ennek megfogalmazásában segítségemre voltak a tesztelés során a naplót kitöltők által feltett kérdések. Így szerepelnek olyan ajánlások pl., hogy melyik napszakban érdemes a naplót tölteni, milyen beszélgetéseket kell lejegyezni, hogyan kell értelmezni a névinterpretáló kérdéseket. Az Útmutató 4 lépésben foglalja össze azt, hogy hogyan érdemes, szükséges vezetni a naplót. A tesztelés során tapasztaltuk, hogy érdemes némiképp irányítani a válaszadó gondolkodását, és jó segítséget nyújt ehhez, ha különböző kérdéseket fogalmazunk meg, melyek alapján a megkérdezett aprólékosan át tudja gondolni a napját. A bevezető, az ajánlások és az útmutató után, - melyeket a kérdezőbiztos segítségével ismertek meg jobban a megkérdezettek - következik a napló napi bontása, mely 1-től 7-ig jelöli a napokat. A naplóban minden egyes 
naphoz két oldal tartozik, minden egyes megjelölt alterrel kapcsolatban 15 névinterpretáló kérdést kellett kitölteni a válaszadónak. (Függelék 2)

\section{Eredmények, következtetések}

Az egocentrikus kapcsolatháló mérete

A hálózat mérete (network size) a társadalmi integrálódás fokát mutatja, és az egyén körüli interperszonális kapcsolatok számával lehet mérni. „, A kapcsolatok kiterjedtségét, gazdagságát legegyszerübben az jellemzi, hogy a megkérdezettek összesen hány személyről számoltak be..." (Angelusz-Tardos, 1988:186). A névgenerátorban a megkérdezettek átlagosan 9,26 altert említettek, a naplóba pedig az egy hét alatt átlagosan 18,17 kapcsolatot jegyeztek. A névgenerátor 8 szituációjába összesen több mint háromezer bejegyzés került, a naplókba pedig egy hét alatt majdnem öt és félezer megvalósuló kontaktust jegyeztek fel a megkérdezettek. Az egyéni kapcsolati hálónak a naplóval tehát valóban szélesebb szeletéről kaptunk képet.

\begin{tabular}{|r|c|c|}
\hline & $\begin{array}{c}\text { Névgenerátor } \\
\mathrm{N}=142\end{array}$ & $\begin{array}{c}\text { Napló } \\
\mathrm{N}=142\end{array}$ \\
\hline Megjelölt alterek száma összesen & 1315 & 2580 \\
\hline mean & 9,26 & 18,17 \\
\hline std.deviation & 5,11 & 12,73 \\
\hline $\min$ & 2 & 2 \\
\hline max & 31 & 93 \\
\hline Bejegyzett kapcsolatok/kontaktusok száma & 3048 & 5451 \\
\hline
\end{tabular}

3. számú táblázat

Az egocentrikus kapcsolati háló mérete - névgenerátor, napló.

Az átlagok közötti különbség szignifikáns ${ }^{6}$, azaz a napló módszerrel szignifikánsan nagyobb hálóméretet lehetett elérni.

\section{A kapcsolati háló összetétele}

A hálózat összetétele (network composition) a kapcsolat jellege, típusa szerint írja le, hogy az egocentrikus kapcsolati háló milyen típusú kapcsolatokból épül fel: inkább közeli családtagok szerepelnek benne (magas rokonsági hányados), vagy inkább a nem rokoni kapcsolatok (barátok, ismerösök, munkatár-

${ }^{6} \mathrm{p}=0,000$; Mean rank 102,46 (névgenerátor) ill. 182,54 (napló) 
sak/iskolatársak, szomszédok) dominálnak (Albert-Dávid, 1994; AngeluszTardos, 1988).

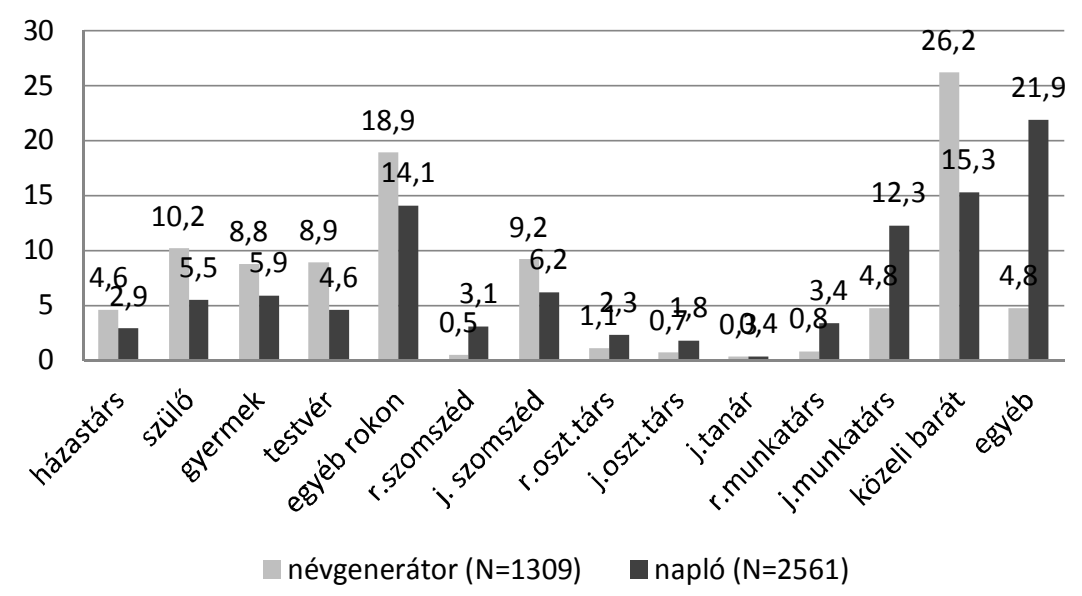

1. ábra

A kapcsolat típusa a két módszer adatai alapján (\%)

A névgenerátor és a napló módszer által feltárt alterek az egohoz füződő kapcsolat típusa szerint szignifikánsan különböznek egymástól ${ }^{7}$.

A névgenerátor hét szituációja alapján legtöbben közeli barátot jelöltek meg, majd az egyéb rokon kategória következett. Ez utóbbi kategóriába leggyakrabban olyanok kerültek, mint a nagyszülő illetve az unoka. A napló módszerrel megjelölt altereket a megkérdezettek leggyakrabban az egyéb kategóriába sorolták. Ebbe a kategóriába sorolták a különböző szakmák, szolgáltatások képviselöit, mint a postás, boltos, orvos, ápoló, fodrász, cukrász, zöldséges, stb., illetve az olyan kapcsolati típusokat, melyek a megkérdezett munkájához köthetők, mint az ügyfél, kliens, vállalkozó, az egyszerüen „,ismerős”-ként megjelöltek illetve a valóban egyéb, sehová nem sorolható altereket. Az egyéb kategóriába tartozó alterek aránya az egocentrikus networkben összefügg a naplóval mért network mérettel: minél nagyobb heti network-öt mért a napló, annál gyakoribb a hálóban az egyéb kategóriába tartozók aránya ${ }^{8}$. Megvizsgáltam, hogy a kapcsolat típusa szerint kik azok, akik mind a névgenerátorban, mind pedig a naplóban

\footnotetext{
${ }^{7} \mathrm{p}=0,000$; A két alter mintát páronként összevetve és konfidencia intervallumokkal vizsgálva, 95\%-os valószínüséggel megállapítható, hogy az eltérések szignifikánsak.

${ }^{8}$ Pearson Corr. $=0,336 ; \mathrm{p}=0,000$
} 
szerepelnek. A két változó között közepesen erős, szignifikáns kapcsolat van ${ }^{9}$. A közeli családtagok nagy része szerepel mindkét módszer esetén, tehát az alapvetően az erős kötésekhez sorolható személyek nagy valószínüséggel szerepelnek mindkét esetben. Ez azonban nem meglepő, lévén a névgenerátor elsősorban az erős kötéseket méri, a naplóba pedig bizonyára feljegyzésre kerülnek azok az alterek, akikkel az egyén közeli családi kapcsolatban áll.

A napló az erős kötések mellett lényegesen nagyobb arányban mutatott gyenge kötéseket is. A naplós módszerrel megjelölt széles egyéb kategória jó mutatója annak, hogy milyen típusú kapcsolatokból tárt fel többet ez a módszer. Míg a névgenerátorban a megkérdezettek inkább az erős kapcsolataikat sorolták fel az alkalmazott szituációkhoz alkalmazkodva, a naplóban megjelöltek olyan kapcsolatokat is, melyek egy más minőségű ego-alter diadikus kapcsolatot jelentenek.

Az átlagos network méretének és összetételének különbségei

A kapcsolati háló méretét és összetételét befolyásoló tényezők vizsgálatához modelleket építettem külön a névgenerátorból és külön a naplóból származó adatokkal. A modell érvényességét és a független változók hatását lineáris regresszió elemzéssel teszteltem. (A regressziós eredményeket lásd Függelék 3.)

\begin{tabular}{|l|c|c|}
\hline \multirow{2}{*}{ network méret } & \multicolumn{2}{|c|}{ Befolyásoló változók } \\
\cline { 2 - 3 } & Névgenerátor & Napló \\
\hline rokonsági hányados & - & $\begin{array}{c}\text { iskolai végzettség } \\
\text { családi állapot }\end{array}$ \\
\hline barátok aránya & $\begin{array}{c}\text { családi állapot } \\
\text { iskolai végzettség }\end{array}$ & $\begin{array}{c}\text { kor } \\
\text { iskolai végzettség } \\
\text { családi állapot }\end{array}$ \\
\hline munkatársak aránya & $\begin{array}{c}\text { családi állapot } \\
\text { iskolai végzettség }\end{array}$ & $\begin{array}{c}\text { családi állapot } \\
\text { gazdasági aktivitás }\end{array}$ \\
\hline szomszédok aránya & kor & gazdasági aktivitás \\
\hline
\end{tabular}

4. számú táblázat

Network méret és network összetétel

A network mérete

A naplóval mért egocentrikus kapcsolati háló méretét szignifikánsan meghatározza az egyén iskolai végzettsége és családi állapota: a magasabb iskolai végzettségüek és a nőtlenek/hajadonok tágasabb kapcsolati hálóval rendelkeznek. A

${ }^{9}$ Chi-square $=574,690 ; \mathrm{df}=14 ;$ Cramer's V=0,474; $\mathrm{p}=0,000$; 
névgenerátorral mért kapcsolati háló nagyságát egyik változó sem befolyásolta szignifikánsan.

\section{A network összetétele}

A két módszerrel mért kapcsolati háló összetételét különböző változók magyarázzák szignifikánsan. A rokonsági hányados esetén a naplónál szignifikáns hatást mutat az ego kora (minél idősebb ego, annál több rokon található az egohálóban), míg ez a névgenerátornál nem mondható el. A másik eltérés a rokonsági hányados magyarázatában a megkérdezett családi állapota volt: a naplónál a házasságban, élettársi kapcsolatban élés volt meghatározó a rokonok arányában, míg a névgenerátor a nőtlenek és hajadonok esetében mutatott nagyobb rokonsági hányadost. A barátok arányát mindkét módszerrel mért adatok esetén szignifikánsan befolyásolja az egyén családi állapota közül a nőtlen/hajadon kategória, de a névgenerátornál az egyén iskolai végzettsége is szignifikáns kapcsolatot mutat a barátok arányával. Minél magasabban kvalifikált ego, annál több barátot jelölt meg a névgenerátorban. A naplónál nem volt mérvadó ego iskolai végzettsége a bejegyzett barátok aránya tekintetében. A munkatársak aránya esetén is egyezés a két módszer adatai között, hogy a gazdasági aktivitás meghatározó, a névgenerátornál azonban ego neme is szignifikánsan hat az említett munkatársak arányára. A networkben megjelenő szomszédok arányát mindkét módszer esetén az egyén kora határozza meg szignifikánsan. Minél idősebb ego, annál több szomszédot jelölt meg. Ez a mindennapos szolidaritás során jelenthet fontos erőforrást.

\section{Az egoháló szelektivitása}

A szelektivitás mutató a különböző társadalmi szürők érvényesülésének indikátora ,, azt fejezi ki, hogy milyen társadalmi-demogárfiai szürők milyen mértékben érvényesülnek a releváns kapcsolatok létrejöttében" (Angelusz-Tardos, 1988:188). A kapcsolathálók szelektivitását olyan demográfiai változók mentén vizsgáltam, mint a nem, kor, iskolai végzettség. Azt néztem meg, hogy az egyes válaszadók hogyan választottak, jelöltek meg altereket az egyes módszerek alapján. A vizsgált változók összefüggését egyszerü korrelációs értékekkel határoztam meg. A korrelációs együtthatók alapján (Pearson) a következő sorrendet lehet felállítani a naplóban megjelölt személyek és az egyének vizsgált jellemzői alapján: 1) legerősebb a kor szerinti szelektivitás 0,67 -es értékkel; 2) nem szerinti választás 0,61-es értékkel; 3) az iskolai végzettség 0,49-es értékkel. A megkérdezettek tehát inkább a hasonlóság elv alapján tartják a kapcsolatot másokkal. A korrelációs értékek minden esetben szignifikánsak. A fenti szelektivitást a névgenerátorban megjelölt alterekkel kapcsolatban is lehetett vizsgálni. 1) kor szerinti szelektivitás 0,68 -as értékkel; 2) iskolai végzettség 0,48-as értékkel; 3 ) nem 0,43 -as értékkel. Az iskolai végzettség hasonló értékkel mutatja a szelekti- 
vitást, mint a napló, a nem szerinti választás azonban a névgenerátorban gyengébbnek tünik. A korrelációs értékek minden esetben szignifikánsak.

A névgenerátorban és a naplóban megemlitett személyek ,átfedettsége”

A következőkben arra keresem a választ, hogy vajon a két módszer mennyire mutatja ugyanazokat a kapcsolatokat, illetve azt, hogy milyen elemekkel gazdagítja egyik módszer a másikat.

Alterek, akik mind a névgenerátorban, mind a naplóban szerepeltek

A megkérdezettek körében, a naplóban megjelölt altereknek átlagosan 37\%-a (std.dev.=0,2172) szerepelt a névgenerátorban is. A két módszer közötti átfedés tehát egyharmados: a két módszerrel megismerhetővé vált alterek közül minden harmadik jelenik meg mindkét adatgyüjtési móddal. Az egokat $(\mathrm{N}=142)$ a névgenerátorban és a naplóban is szereplő alterek átlagos megjelenési aránya alapján 4 csoportra osztottam: 1) nagyon kevés átfedés az alterek között; 2) félig átfedés; 3) inkább átfedések; 4) nagyon sok átfedés ${ }^{10}$.

A megkérdezettek nagyobb része esetén beszélhetünk a névgenerátorral, illetve a naplóval gyüjtött adatok maximum felének egyezéséről. A két módszerben megjelölt alterek tehát nem feltétlenül egyeznek meg, a napló új elemeket tartalmaz a névgenerátorhoz képest.

A network mérete és a két módszerrel gyüjtött adatok közötti átfedést mutató változó között negatív irányú szignifikáns összefüggés van: minél nagyobb az egocentrikus háló mérete a naplós adatok alapján, annál kevesebb átfedést tartalmaz a két módszer ${ }^{11}$.

Alterek, akik csak a naplóban szerepeltek

A naplóban megemlítettek közül minden harmadik alter (31\%) szerepelt ugyanazon ego által kitöltött névgenerátorban is, azaz a naplóban említettek nagy része (69\%) a névgenerátor kérdéseiben említett alterekhez képest új kapcsolatot je-

$\left.{ }^{10} 1\right)$ nagyon kevés átfedés az alterek között- a névgenerátorban megjelölt altereknek kevesebb, mint negyede szerepelt a naplóban; minden harmadik megkérdezett esetében (33\%; 47 fö) van maximum 25\%-os átfedés a naplóban és a névgenerátorban megjelölt alterek között; 2) félig átfedés - a névgenerátorban megjelölt alterek több mint negyede és maximum fele szerepelt a naplóban; a megkérdezettek 44\%-a (63fó) esetén a bejegyzett alterek maximum fele egyezik meg a két módszer esetén; 3) inkább átfedések - a névgenerátorban megjelölt alterek több mint fele, de maximum háromnegyede szerepelt a naplóban; a megkérdezettek 14,8\% (21fó) esetén regisztráltam maximum 75\%-os átfedés; 4) nagyon sok átfedés - a névgenerátorban szereplő alterek közül mindenki szerepelt a naplóban; a megkérdezetteknek 7,7\%-a (11 fö) jelölte mindkét módszerrel szinte ugyanazokat az altereket, itt az átfedés több mint 75\%-os.

${ }^{11}$ Pearson Corr. $=-0,375 ; \mathrm{p}=0,01$ 
lent. Úgy tủnik, tehát, hogy az erős kötéseken kívül, jelentős a naplóban megjelölt új alterek aránya.

\section{Alterek, akik csak a névgenerátorban szerepeltek}

Természetesen a névgenerátorban is vannak olyan alterek, amelyek a naplóban nem jelennek meg. A névgenerátorban megjelölt alterek 36,5\%-a nem szerepel ugyanazon személy által kitöltött naplóban, nagy részüket $(63,5 \%)$ tehát a napló módszerrel is lehet mérni. A névgenerátorral felmért támogató kapcsolati hálóhoz tartozó egyénekkel a megkérdezettek nagy valószínüség szerint találkoztak is a napló módszerrel vizsgált héten. Ezek a kapcsolatok tehát eleget tesznek az erős kötések azon kívánalmainak is, hogy gyakori találkozás valósul meg. A mintába került férfiakra, a középkorúakra (50-59 évesek) illetve az alacsony iskolai végzettséggel rendelkezőkre jellemzőbb az, hogy nagy az átfedés a két módszerrel megjelölt alterek tekintetében. Az alacsony iskolai végzettséggel rendelkezők körében azonban szignifikánsan alacsonyabb a megjelölt alterek száma, azaz kisebb a network méretük.

\section{Összefoglalás}

A kutatás során bebizonyosodott, hogy a napló, mint mérőeszköz jó esélyt ad arra, hogy az egocentrikus kapcsolati háló viszonylag széles, összetett, aktív és aktuális részét ismerjük meg. A két módszerrel felmért egocentrikus kapcsolati hálóhoz zömében olyan személyek tartoznak a megkérdezettek esetén, aki a vizsgált személyek támogató, de egyben aktív és aktuális networkjét is gazdagítják. A megkérdezettekkel kapcsolatban elmondható, hogy a névgenerátorban feltüntetett altereknek valamivel több, mint harmada (36,5\%) olyan kapcsolat, akivel a találkozás nem rendszeres, hiszen a naplóval vizsgált héten az adatok szerint nem volt megvalósuló kontaktus. Ezeket a kapcsolatokat nevezhetjük az ego által bizonyos helyzetekben vélt támogató kapcsolatainak. Ezek a kapcsolatok bekerülnek ugyan az egyén névgenerátorral mért kapcsolati hálójába, de nem biztos, hogy ezekre a kapcsolatokra az egyén valóban számíthat is a megjelölt esetekben.

A naplóba bejegyzett alterek jelentős hányadát alkotják az olyan, tágabb kapcsolati hálóhoz tartozó kapcsolatok, melyeket az egyéb módszerekkel nem lehet ilyen részletesen megismerni. Az egyént körülvevő aktív kapcsolati háló tanulmányozása közelebb vihet a gyenge kapcsolatok részletesebb megismeréséhez, illetve a network alakulásának, dinamikájának kutatásához. A két módszerben (névgenerátor ill. napló) megjelölt alterek nem feltétlenül egyeznek meg, a napló új elemeket tartalmaz a névgenerátorhoz képest. A naplóban megemlítettek közül minden 
harmadik alter szerepelt ugyanazon ego által kitöltött névgenerátorban is, azaz a naplóban említettek nagy része a névgenerátor kérdéseihez képest új kapcsolatot jelent. Minél nagyobb az egocentrikus háló mérete a naplós adatok alapján, annál kevesebb átfedést tartalmaz a két módszer. Az adatok alapján látható, hogy olyan kapcsolatok maradhatnak ki egy névgenerátorral történő adatfelvétel során, akik megtalálhatók az egyén körül, de akik társas támogatására ego nem feltétlenül számít. Viszont, ha ezek a kapcsolatok a naplóval megismerhetővé válnak és a névinterpretáló kérdések mentén az is nyilvánvalóvá válik, hogy fontos kapcsolatok ego számára, akkor az egocentrikus hálónak már egy újabb szeletét ismerhetjük meg. Erre lehet jó a napló módszer.

\section{Konklúzió}

A napló alkalmas a hálózati erőforrások viszonylag nagy szeletének feltérképezésére. A névgenerátorból származó információkkal kiegészítve még informatívabb képet kaphatunk az egocentrikus kapcsolati hálót illetően.

A napló módszer alkalmazásával leírhatóvá válhat az egyén kapcsolati hálójának struktúrája mellett annak dinamikája is: hogyan változik az egyént körülvevő kapcsolatok mérete, összetétele, sőt a meglévő kapcsolatok erősségének változása is detektálható, illetve az új kapcsolatoknak az egocentrikus hálóba történő beépülése is nyomon követhető. Ehhez olyan panelvizsgálatot szükséges folytatni, ahol éveken keresztül módunkban áll megfigyelni ugyanazon egyének kapcsolathálózatának változásait bizonyos körülmények megváltoztatásával.

\section{Felhasznált irodalom}

1. Albert F.-Dávid B.: Magyarországon tanuló külföldi diákok kapcsolathálózati jellemzői. In. Szociológiai Szemle, 1994/3. 81-91.

2. Angelusz Róbert - Tardos Róbert (1988): A magyarországi kapcsolathálózatok néhány sajátossága. Szociológia, 2 . sz.

3. Bernard, H.R. et al. (1990): Comparing Four Different Methods for Measuring Personal Social Networks. Social Networks 12. p. 179-215.

4. Burt, R.S. (1984); Network Items and the General Social Survey. Social Networks, 6 (4), p. 293-339.http://dx.doi.org/10.1016/0378-8733(84)900078

5. Campbell Karen E.- Lee, B.A. (1991): Name Generators in Surveys of Personal Networks. Social Networks 13. p. 203-221. 
6. Chua, V.- Madej J. - Wellman B. (2009): Personal communities: The world according to me. http://homes.chass.utoronto.ca/ wellman/publications/personal/handbookcommunity.pdf

7. Erickson, B. (2004): The Distribution of gendered social capital in Canada.

8. Flap, H. and Volker, B. edit: In Creation and returns of social capital: A new research program. London: Routledge, p. 27-50.

9. Feld, S. L. - Suitor, J. L. - Hoegh, J.G. (2007): Describing Changes in Personal Networks over Time. Field Methods, 19. p. 218-236.

10. Fischer C. (1982a): To Dwell Among Friends. Berkeley: University of California Press.

11. Fischer C. (1982b): What Do We Mean by 'Friend'? An Inductive Study. Social Network, 3. p. 287-306

12. Freeman, C.L. - Thompson C.R. (1989): Estimating Acquaintanceship Volume. In: Kochen, M. edit: The Small World. Norwood. NJ, Ablex, p. 147-158.

13. FU, Yang-chih (2005): Measuring personal networks with daily contacts: a single-item survey question and the contact diary. Social Networks 27. p. 169-186.

14. Fu, Yang-chih (2007): Contact Diaries: Building Archives of Actual and Comprehensive Personal Networks. Field Methods, 19. p. 194-217.

15. Fu, Yang-chih (2008): The Immediate Returns on Time Investment in Daily Contacts. Exploring the Network-Overlapping Effects from Contact Diaries. In: Hsung, R.M. - Lin, N. - Breiger, R. edit: Contexts of Social Capital. Social Networks in Markets, Communities and Families. Routledge, Taylor and Francais Group. New York, London.

16. Granovetter, M.S. (1973): The Strength of Weak Ties. American Journal of Sociology, Volume 78, Issue 6. p. 1360-1380.

17. Granovetter, M.S. (1974): Getting a Job. Study of Contacts and Careers. Cambridge: Harvard University Press

18. Granovetter, M.S. (1982): A gyenge kötések ereje. A hálózatelmélet felülvizsgálata. In: Angelusz R. - Tardos R. szerk. (1991): Társadalmak rejtett hálózata. Budapest, Magyar Közvéleménykutató Intézet. p. 371-400.

19. Gurevich, M. (1961): The social structure of acquaintaceship networks. Massachusetts Institute of Technology.

20. Hogan, B. - Carrasco, J.A. - Wellman, B. (2007): Visualizing Personal Networks: Working with Participant-aided Sociograms. Field Methods, 19. p. 116-144.

21. Killworth P.D. et al. (1990): Estimating the size of personal networks. Social Networks 12. p. 289-312.

22. Laumann E. (1973): Bonds of Pluralism. New York: Wiley. 
23. Lin, N.-Dumin, M. (1986): Access to occupations through social ties. Social Networks, 8. p. 365-383.

24. Lin, N. (2001): Social Capital. Cambridge: Cambridge University Press.

25. Lonkila, M. (1999): Social Networks in Post-Soviet Russia. Countinuity and Change in the Everyday Life of St.Petersburg Teachers. Helsinki, 1999. ISBN 951-45-8742-1 (PDF version) Helsingin yliopistion verkkojulkaisut

26. Marsden, P.V. (1987): Az amerikaiak fontos beszélgetési hálózatai. In: Angelusz R. - Tardos R. (1991): Társadalmak rejtett hálózata. Budapest, Magyar Közvéleménykutató Intézet. p.353-370.

27. Marsden, P.V. (2005): Recent Developments in Network Measurement. In: Carrington P.J.-Scott J.-Wasserman S. edit.: Models and Methods in Social Network Analysis. Cambridge University Press

28. Mccallister, L.-C. S. Fischer (1978): A procedure for surveying personal networks. Sociological Methods \& Research, 7. p. 131-148.

29. Mccarty, C. (2002): Measuring structure in personal networks. Journal of Social Structure, 3:1

30. Pool I. De S.-Kochen, M. (1978): Contacts and influence. Social Networks, 1. (1978/1979) p. 5-51.

31. Snijders, T.A.B.(1999): Prologue to the measurement of social capital. La Revue Tocqueville 20 (1). p. 27-44.

32. Szalai Sándor szerk. (1978): Idő a mérlegen. Budapest, Gondolat Könyvkiadó.

33. van der Gaag, M.- Snijders T.- Flap, H. (2008): Position generator measures and their relationship to other social capital measures. In: LIN, N. AND ERICKSON, B.H. edit.: Social Capital: An International Research program. New York: Oxford University Press. p. 27-48.

34. WELLMAN, B. (1979): The community question. American Journal of Sociology 84: p. 1201-31.

35. WELLMAN, B. (2001a): Physical place and cyber place: The rise of personalized networking. International Journal of Urban and Regional Research, 25(2). p. 227-252.

36. WELLMAN, B. (2001b): The persistence and transformation of community: From neighbourhood groups to social networks. In: Report to the Law Commission of Canada. Ottawa http://homes.chass.utoronto.ca/ wellman/publications/lawcomm/lawcomm7. PDF 


\section{Függelék}

\section{Függelék 1. A kutatásban alkalmazott névgenerátor szituációi}

1. Időnként az emberek összejönnek egymással: meglátogatják egymást, vendégeket hívnak, elmennek együtt sétálni, kirándulni, együtt vacsoráznak, stb. Kik azok az emberek, akikkel általában így össze szokott jönni?

2. Tételezzük fel, hogy Ön hirtelen pénzzavarba kerül. Kitöl kérne kölcsön ebben az esetben? (Személytől, nem pedig banktól vagy más intézménytől!)

3. Időnként az emberek kisebbfajta segítséget kérnek egymástól, például segítséget kérnek a ház körüli kisebb munkálatokhoz, vagy például kölcsönkérnek ezt-azt, vagy kisgyermek felügyeletéhez. Kiktől szokott Ön általában ilyen kisebb jellegü segítséget kérni? Vagy kihez fordulna ilyen jellegü segítségért?

4. Kérem, most képzelje el, hogy egy-két hétre elutaznának és a lakás üresen maradna. Sokan ilyenkor megkérnek valakit, hogy gondoskodjon a lakásról. Pl. öntözze meg a virágokat, ürítse ki a postaládát. Kihez szokott Ön fordulni, amikor ilyen típusú segítségre van szüksége? Vagy kihez fordulna ilyen jellegü segítségért?

5. Időnként az emberek beszélgetni szoktak a családjukkal, munkájukkal, munkahelyükkel összefüggő dolgokról. Kikkel szokta Ön az ilyen jellegü kérdéseket megbeszélni?

6. Amikor utoljára olyan jelentős döntések előtt állt, mint például állásváltoztatás, vagy költözés, vagy lakásvásárlás, vagy más ehhez hasonló, kihez fordult tanácsért, információért? Vagy kihez fordulna ilyen jellegü segítségért?

7. A családtagjain kívül szokott-e Ön időnként egészen személyes, bizalmas dolgokról, problémákról másokkal beszélgetni? Ha van ilyen, megmondaná, hogy kicsoda?

A névgenerátorban használt névinterpretáló kérdések: a kapcsolat természete; az alter neme; kora; iskolai végzettsége; beszélgetési gyakoriság; mennyire tartja szorosnak az alterrel a kapcsolatát; milyen messze lakik alter egotól.

Az általam alkalmazott névgenerátorban nem volt limitálva a megadható alterek száma, illetve a megjelölt alterek mindegyikével kapcsolatban kértem az adott névinterpretáló kérdéseket, tehát nem volt ebben az esetben sem szükítés.

\section{Függelék 2. A naplóban használt névinterpretáló kérdések}

1. demográfiai adatok: az alter neme; kora; iskolai végzettsége; foglalkozása; lakóhelye 
2. az ego-alter kapcsolatra vonatkozó kérdések: mióta ismeri Ego Altert; a kapcsolat természete; járt-e már Ego Alter lakásán; beszélgetési gyakoriság; általában mennyire élvezi ego a megjelölt társaságát; megbeszélne-e fontos dolgokat Ego a megjelölt személlyel

3. az adott találkozásra vonatkozó kérdések: a találkozás helyszíne; a beszélgetés formája; ki kezdeményezte a beszélgetést a beszélgetés alkalmával jelenlévők száma

\section{Függelék 3. A regresszió elemzés statisztikái}

A. A network méretre ható tényezők vizsgálatához használt logisztikus regresszió statisztikái

\begin{tabular}{|l|c|c|c|}
\hline & \multicolumn{3}{|c|}{ Függő: network mérete (napló) } \\
\hline Független változók & Szignifikancia & $\mathrm{B}$ & hatás $(\beta)$ \\
\hline Iskolai végzettség & 0,000 & 7,160 & 0,316 \\
\hline Családi állapot (házas-e) & 0,029 & 6,332 & 0,185 \\
\hline Megmagyarázott hányad & \multicolumn{3}{|c|}{0,000} \\
\hline Modell szignifikanciája & \multicolumn{3}{|c|}{0,000} \\
\hline
\end{tabular}

B. A network összetételre ható tényezők vizsgálatához használt logisztikus regresszió statisztikái

\begin{tabular}{|c|c|c|c|c|c|c|}
\hline \multicolumn{7}{|c|}{$\begin{array}{c}\text { Függö: network összetétele } \\
\text { rokonsági hányados }\end{array}$} \\
\hline & \multicolumn{3}{|c|}{ névgenerátor } & \multicolumn{3}{c|}{ napló } \\
\hline Független változók & Szignifikancia & B & hatás $(\beta)$ & Szignifikancia & B & hatás $(\beta)$ \\
\hline Ego kora & - & - & - & 0,003 & 0,003 & 0,252 \\
\hline Iskolai végzettsége & 0,013 & $-0,0872$ & $-0,213$ & 0,007 & $-0,074$ & $-0,233$ \\
\hline Családi állapota (házas-e) & 0,001 & $-0,172$ & $-0,277$ & 0,017 & 0,081 & 0,207 \\
\hline Megmagyarázott hányad & \multicolumn{3}{|c|}{$10 \%$} & \multicolumn{3}{c|}{$15,3 \%$} \\
\hline Modell szignifikanciája & \multicolumn{3}{|c|}{0,000} & \multicolumn{3}{c|}{0,000} \\
\hline \hline
\end{tabular}

\begin{tabular}{|c|c|c|c|c|c|c|}
\hline \hline \multicolumn{9}{|c|}{$\begin{array}{c}\text { Függő: network összetétele } \\
\text { batárok aránya }\end{array}$} \\
\hline & \multicolumn{3}{|c|}{ névgenerátor } & \multicolumn{3}{c|}{ napló } \\
\hline Független változók & Szignifikancia & B & hatás $(\beta)$ & Szignifikancia & B & hatás $(\beta)$ \\
\hline Iskolai végzettsége & 0,033 & 0,076 & 0,182 & - & - & - \\
\hline Családi állapota (házas-e) & 0,001 & 0,183 & 0,288 & 0,001 & 0,131 & 0,298 \\
\hline Megmagyarázott hányad & \multicolumn{3}{|c|}{$9,5 \%$} & & \multicolumn{3}{c|}{$8 \%$} \\
\hline Modell szignifikanciája & \multicolumn{3}{|c|}{0,001} & \multicolumn{3}{c|}{0,01} \\
\hline
\end{tabular}




\begin{tabular}{|c|c|c|c|c|c|c|}
\hline \multicolumn{7}{|c|}{$\begin{array}{c}\text { Függö: network összetétele } \\
\text { munkatársak aránya }\end{array}$} \\
\hline & \multicolumn{3}{|c|}{ névgenerátor } & \multicolumn{3}{c|}{ napló } \\
\hline Független változók & Szignifikancia & B & hatás $(\beta)$ & Szignifikancia & B & hatás $(\beta)$ \\
\hline Ego neme & 0,010 & $-0,044$ & $-0,225$ & - & - & - \\
\hline $\begin{array}{c}\text { Gazdasági aktivitása } \\
\text { (dolgozik-e) }\end{array}$ & 0,046 & $-0,033$ & $-0,174$ & 0,000 & $-0,132$ & $-0,420$ \\
\hline Megmagyarázott hányad & \multicolumn{3}{|c|}{$8 \%$} & & \multicolumn{3}{c|}{$17 \%$} \\
\hline Modell szignifikanciája & \multicolumn{3}{|c|}{0,002} & & \multicolumn{3}{c|}{0,000} \\
\hline \hline
\end{tabular}

\begin{tabular}{|c|c|c|c|c|c|c|}
\hline \hline \multicolumn{9}{|c|}{$\begin{array}{c}\text { Függő: network összetétele } \\
\text { szomszédok aránya }\end{array}$} \\
\hline & \multicolumn{3}{|c|}{ névgenerátor } & \multicolumn{3}{c|}{ napló } \\
\hline Független változók & Szignifikancia & B & hatás $(\beta)$ & Szignifikancia & B & hatás $(\beta)$ \\
\hline Ego kora & 0,000 & 0,0027 & 0,306 & 0,006 & 0,0023 & 0,243 \\
\hline Megmagyarázott hányad & \multicolumn{3}{|c|}{$8,6 \%$} & \multicolumn{3}{c|}{$5 \%$} \\
\hline Modell szignifikanciája & \multicolumn{3}{|c|}{0,000} & \multicolumn{3}{c|}{0,006} \\
\hline
\end{tabular}

\section{Huszti Éva}

Debreceni Egyetem Egészségügyi Kar, 4400 Nyíregyháza, Sóstói u. 2-4. 